\title{
Temporary Compensation Policy For Village Land Taken Over By The Government For Public Interest
}

\author{
Suhadi $^{1}$ and Sudijono Sastroatmodjo ${ }^{2}$ \\ \{suhadi@mail.unnes.ac.id ${ }^{1}$, sudijonosastroatmodjo@mail.unnes.ac.id² \\ ${ }^{1.2}$ Faculty of Law, Universitas Negeri Semarang, Indonesia
}

\begin{abstract}
Village land that is used for public purposes will be compensated replacement land under the Law on Acquisition of Land for Public Interest. This paper reveals that replacement land cannot always be held in accordance with the planned stages and time of land acquisition. In practice, money as temporary compensation is more used than replacement land, as compensation for village land that is used for public purposes. The government adopted a temporary compensation policy to take over village land and agreed with the parties concerned, so that land acquisition activities could be carried out according to the planned stages and time. However, the provision of temporary compensation in the form of money needs to be regulated more clearly so that the land acquisition regulations and village land regulations are aligned.
\end{abstract}

Keywords: village land, land acquisition, temporary compensation, replacement land

\section{Introduction}

The development carried out by the government is mainly infrastructure development requires large amounts of land. In the regulation of acquisition of land for public interest in Indonesia, infrastructure development for public interest comes from the responsibility of the state to realize public welfare as contained in the constitution, among others through state control over land. [1] Data from several ministries shows that the land to be used for the construction of electricity and energy infrastructure, toll roads, airports, ports, dams, and drinking water needed by the government covers an area of 140,704 hectares. Land for industrial land reaches 1,200 ha. In 2005-2019, land needs were estimated at 133,657 hectares, consisting of 456 hectares for public housing, 21,172 hectares for roads, 111,437 hectares for water resources, and 592 hectares for copyright.[2] More specifically in the construction of toll roads, Semarang-Solo toll road requires an area of 5,967,074 hectares consisting of 3,135 parcels of land [3], so the government needs to take over lands that are controlled or owned by other parties, including village land.Village land consists of "bengkok land and titisara land"[4]. "Bengkok land" is land whose tenure is given to village officials as a form of respect for the duties and obligations that are carried out, which are generally in the form of agricultural land. In general, bengkok land is good and strategic soil. Unlike the bengkok land, "Titisara Land is a village land that is generally in the form of agricultural land, which is leased to community members through open auctions. This land is also called the village treasury. The purpose of this land control by the village is as a source of village income to carry out village management 
and development[5][6]. Therefore it could be stated that village-owned land is a land that is important for the village, which will be used to achieve villager welfare as the recompense for the village head and officials or as a revenue stream for the village's finance.

The regulation used as the basis for the government to take over village land for the implementation of development is the Law Number 2 of 2012 and its implementing regulations. Village land that was taken over by the government was compensated replacement land. Compensation village land for public interest is given at the time of the release of village land, even though the replacement land as a form of compensation does not yet exist, as stipulated in Article 77 of Presidential Regulation Number 71 of 2012. Regulation of the Minister of Home Affairs of the Republic of Indonesia Number 1 of 2016 which forms the basis of village land management also stipulates that village land can be used for public purposes by means of exchange, which can be done even though there is no replacement land. In the event that replacement land is not yet available, compensation for village land is provided in the form of money, as temporary compensation. The compensation money must be used to buy replacement land.

The temporary compensation policy is carried out by the government because of 2 (two) things, first, land acquisition must proceed according to the stages and time specified in the legislation, and secondly, village land as a village asset must be protected by substituting other land of the same quality. Although the temporary compensation is well intentioned, the arrangements need to be improved so that it is more synchronous with the laws on land acquisition and the laws on village land. The discussion in this paper begins with the reality of the use of village land for development in the public interest, the regulation of village land compensation used for public interest, and a temporary compensation policy for village land used for public interest.

\section{Research Method}

This research is doctrinal legal research or normative legal research.[7] In this study law is defined as rules as contained in laws, legal documents and research results. Primary, secondary and tertiary legal materials in the form of laws and regulations, decisions and other legal documents are the main data sources in this study.[8] The legislation and the legal documents analyzed consist of Law No.2 of 2012, Presidential Regulation No. 71 of 2012, Law No. 6 of 2014, and Regulation on Village Asset Management. This study uses text analysis of regulations to see the contents of regulations, analysis of social, economic and political contexts that influence the formation of laws and regulations, and analysis of legal and regulatory praxis about land acquisition and village land. [9]

\section{Result and Discussion}

\subsection{The Reality of Village Land that Is Used for Public Purposes}

Land for road construction including toll roads, power plants, airports, some of which are filled with village land taken over by the government on a public interest basis. The village land in Tegal Regency which is used for the construction of the Pejagan-Pemalang toll road, covers 25 villages located in 9 subdistricts, which as a whole covers $312,716 \mathrm{~m} 2$. [10] Village land in Semarang Regency used for toll road construction is in 9 villages in 4 sub-districts with a total 
area of 119,153 m2. [11] In addition, according to Senthot Sudirman, the village land for the Solo-Mantingan toll road construction that cannot be acquired until October 2014, amounted to 29 parcels of land with an area of $45,206 \mathrm{~m} 2$ or $1.94 \%$ of the total land assets of villages affected by toll road construction. [12] The data shows that the number of village land assets that have been successfully acquired is greater $(98.06 \%)$, so it can be said that the village land used for the construction of the Solo-Mantingan toll road is up to hundreds of hectares.

The village land used for the construction of the Central Java Power Plant 2 GW consists of 6 plots of land covering an area of $1,959 \mathrm{~m} 2$. [13] The village land used for the construction of the Kertajati airport in West Java Province is more than 81 hectares, which is located in Bantarjati, Kertasari and Kertajati village. [14]

\subsection{Regulation of Compensation for Village Land that Is Used for Public Purposes}

The limitations on village land used for public purposes as regulated in the Law on Acquisition of Land for Development in the Public Interest, are:

a. land for public use taken through land acquisition will be compensated in the form of money, resettlement, replacement land, ownership of shares and other forms agreed by both parties (Article 36)

b. Compensation for customary land rights is given in the form of substitute land, resettlement, or other forms agreed by the indigenous peoples concerned (Explanation of Article 40).

c. Other forms of compensation for village land are in the form of temporary money, meaning that the compensation money will be used to buy replacement land.

d. The procedure for providing compensation in the form of replacement land is contained in Presidential Regulation No. 71 of 2012.

Article 77 Presidential Regulation of the Republic of Indonesia Number 71 of 2012 regulates the following matters:

a. replacement land as compensation for village land is provided by parties who will use village land for public use through the Land Acquisition Implementation Team..

b. The compensation is provided by an agency that requires land after receiving a written request from the Chairperson of the Land Acquisition Officer

c. Replacement land is given for and on behalf of the Rightful Party

d. Provision of replacement land is carried out through buying and selling or other agreed methods in accordance with statutory provisions.

e. Giving compensation is carried out simultaneously with the release of rights by the rightful party without waiting for the availability of replacement land.

f. During the process of providing replacement land, the funds for providing replacement land are deposited in the bank by and on behalf of the agency requiring land.

g. Implementation of the provision of replacement land shall be carried out no later than 6 (six) months after the determination of the form of compensation by the Implementor of Land Acquisition

Regulation of the Minister of Home Affairs of the Republic of Indonesia Number 1 of 2016 stipulates that village land as a village asset can be transferred to another party for public interest through exchange. One important principle in relation to the exchange of village land for public use is that exchange is carried out in accordance with statutory provisions. In the concept of 
land exchange, there must be land to be exchanged. This means that village land that is transferred to another party must be exchanged for land owned by another party. Thus, village land that is transferred to another party will get a replacement land. Article 33 Regulation of the Minister of Home Affairs of the Republic of Indonesia Number 1 of 2016 stipulated that the exchange of village land is carried out after an agreement of compensation is in accordance with the price that benefits the village by using the fair value calculated by appraisers. If the replacement land is not yet available, the replacement land can be given in the form of money first. Reimbursement in the form of money must be used to buy an equivalent replacement land.

The stages of exchange of village land for public use based on Article 34 of the Minister of Home Affairs Regulation of the Republic of Indonesia Number 1 of 2016, are:

a. The Village Head submits a letter to the Regent or Mayor about the results of the Village Deliberation regarding the exchange of land belonging to the Village with the prospective location of the replacement land located in the local village.

b. The Village Head submits the permit application to the Regent / Mayor, henceforth the Regent / Mayor continues the permit application to the Governor.

c. If the prospective replacement land location is not available in the local village, the following steps will be carried out:

1) The Regent / Mayor conducts a field review and data verification to obtain material and formal truth as outlined in the official report. A field survey was carried out to see and know materially the physical condition of the location of village-owned land and the location of a potential replacement for villageowned land. Data verification is carried out to obtain formal evidence through meetings in the village attended by elements from the Village Government, $\mathrm{BPD}$, the party conducting the exchange, the land owner used for replacement land, the Subdistrict apparatus, the District and Provincial Regional Governments, as well as parties and / or other related agencies. The Minutes are signed by the parties and / or other relevant agencies, which contain a) the results of village deliberations, b) location, size, fair price, type of village land based on their use, and c) proof of ownership of the village land in exchange and its successor.

2) The results of the field review and verification of the data are submitted to the Governor as consideration for granting approval.

3) Before granting approval, the Governor can conduct field visits and verify data. The field visit and verification of the data are the same as those described

4) After the Governor gives his approval, then the Village Head establishes a Village Regulation regarding the exchange of land belonging to the village.

d. The Governor reports the results of the exchange with the Minister

Based on Presidential Regulation No. 71/2012 and Regulation of the Minister of Home Affairs of the Republic of Indonesia No. 1/2016, it can be stated that village land used for public purposes should in principle be replaced with land, even though the terms used are not the same. In Presidential Regulation Number 71 of 2012, the term replacement land is used, while in the Republic of Indonesia Minister of Domestic Affairs Regulation Number 1 of 2016, the term exchange is used. The two terms are the same substance, that is, village land that is used for public purposes is replaced by land to ensure the sustainability of the function of village land.

\subsection{Temporary Compensation Policy for Village Land}


Temporary compensation policy carried out by the government for at least 2 (two) reasons, first, land acquisition must proceed according to the stages and time specified in the law, and secondly, village land as village assets must be protected by replacing quality land same. The stages of activities and the time of land acquisition have been determined limitatively by the law on land acquisition and its implementing regulations. Stages of land acquisition activities include planning, preparation, implementation and delivery of results. Provision of compensation is part of the stages of the implementation of land acquisition. The period of time at the stage of implementing land acquisition is determined at the earliest 200 days if there are no objections and lawsuits on state administration and the maximum is 288 days if there are complaints and objections.

Land acquisition regulations specify that the form of compensation for village land used in the public interest is replacement land. On the other hand, Law of the Republic of Indonesia Number 6 of 2014 and Regulation of the Minister of Home Affairs of the Republic of Indonesia Number 1 of 2016 also regulates the mechanism of village land release and determines the criteria for replacement land for village land used for public purposes. Both of these can lead to the release of village land and the acquisition of replacement land can not always be done in accordance with the time allotted. As a result, replacement land is not yet available but the release of village land must be done so that land acquisition can continue at the next stage. For example, substitute land for village land in the Semarang Regency area used for the construction of the Semarang-Solo toll road, village land in Batang Regency used for power plant construction cannot be provided at the time of village land release, so compensation is given in money. Provision of temporary compensation is a solution to the problem of unavailability of replacement land. This policy is carried out because in the context of land acquisition, one of the important and decisive things is the availability of land. Land that is not available on time can have an impact on many aspects of land acquisition, especially development costs that can exceed planning.

Village land based on Article 76 paragraph (1) of the Law of the Republic of Indonesia Number 6 of 2014 is part of village assets. Village land as a village asset shows that village land belongs to the village, not to individuals. Village land ownership is communal ownership managed by the village. Article 34 paragraph (1) Government Regulation of the Republic of Indonesia Number 47 of 2015 stipulates that village land management is one of the village's authorities, while Article 100 paragraph (3) stipulates that the results of village land management can be used for additional allowances for village heads and village officials. Regulation of the Minister of Home Affairs of the Republic of Indonesia Number 1 of 2016 concerning Management of Village Assets confirms that village land is a strategic village asset as the original wealth of the village. Thus village land used for public purposes must be replaced with other land of equal quality. The goal is that the village land can still function as a genuine asset of the village that is strategic in order to realize the welfare of the village community. In fact, finding replacement land that is of equal quality to village land is not easy. For example, prospective land substitutes for village land in the Semarang Regency area do not meet the requirements as determined by the law on village land, so they must be consulted with the Regent and Governor. This process requires quite a long time, so that the village government is not considered to make mistakes in procuring replacement land.

Regulations that need to be improved in the context of compensation for village land are Article 77 paragraph (6) of Presidential Regulation Number 71 of 2012. The article stipulates that the money that will be used to provide replacement land, is deposited in banks by and on behalf of agencies that require land, not in the name of the party entitled, in this case the village. Normatively, this provision causes that at the time of compensation no one is given either a 
replacement land or money (which will be used to obtain replacement land) by the agency that requires the land through the executor of the land acquisition. In fact, Article 77 of Perpres 71 of 2012 clearly stipulates that the granting of compensation is carried out simultaneously with the release of rights by the rightful party without waiting for the availability of replacement land (can be realized in the form of money).

The provisions of Article 77 paragraph (6) of Perpres 71 of 2012 that the money to be used to provide replacement land, is determined to be deposited at the bank by and on behalf of the agency requiring this land is also out of sync with Article 33 of the Minister of Home Affairs Regulation of the Republic of Indonesia Number 1 of 2016 , which stipulates that if replacement land is not yet available, compensation can be given in the form of money, for which the compensation money must be used to purchase the equivalent replacement land. In other words, Regulation of the Minister of Home Affairs of the Republic of Indonesia Number 1 of 2016 confirms that if replacement land is not yet available, compensation is provided in the form of money. For example, in the construction of the Semarang-Solo toll road concerning village land in the Regency of Semarang, compensation is provided in the form of money deposited in a village account with a note that there is a Commitment Statement from the Commitment Making Official to cover the costs of finding replacement land as mandated in Article 44 Permendagri Number 1 of 2016, the administrative financing of the exchange process until the completion of the certificate of replacement village land as referred to in Article 33, Article 38 and Article 42 shall be borne by the requesting party. There are two important things in the practice of providing compensation for village land for which replacement land is not yet available, namely money deposited in the village account, not in the account of the agency requiring village land, and secondly all administrative costs incurred to obtain replacement land until registration (certification ) is the responsibility of agencies that require land. This can be interpreted that the full compensation money can be used to obtain replacement land without having to reduce administrative costs.

\section{Conclusion}

The temporary compensation policy implemented by the government is a solution to overcome the problem of the availability of land in the public interest. Through a temporary compensation policy the land acquisition process can be guaranteed in accordance with the planned stages and time. In addition, the existence of village land as a strategic village asset can also be protected by replacing it with quality land. The implication of this study is that the policy for providing temporary compensation needs to be more clearly regulated in legislation so that it does not conflict with regulations on land acquisition or regulations on village land.

\section{References}

[1] Suhadi and Dani Muhtada. Transformation of the Meaning of Public Interest in the Indonesian Regulations on Land Acquisition: A Sustainable Development Perspective. Advances in Social Science, Education and Humanities Research, volume 358 3rd International Conference on Globalization of Law and Local Wisdom (ICGLOW 2019)). Atlantis Press p 69-72 (2018)

2] Suhadi, Suhadi. "Harmonization of Regulation on Land Acquisition For The Infrastructure Development Under Public-Private Partnership Scheme In Indonesia" Advances in Social Science, 
Education and Humanities Research, volume 192 Proceedings of the 1st International Conference on Indonesian Legal Studies (ICILS 2018). Atlantis Press p 1 (2018)

[3] Decree of the Governor of Central Java Number 620/8 of 2015 concerning Approval of the Renewal of the Establishment of the Trans Java Toll Road Development in the Province of Central Java

[4] Article 1 number 10 Minister of Domestic Affairs Regulation No.4 of 2007 concerning Guidelines for Management of Village Assets

[5] Baiquni, M. "The Economic and Ecological Crises and Their Impact on Livelihood Strategies of Rural Household in Yogyakarta" Titus, Milan J \& Paul P.M. Burgens. Rural Livelihood, Resources and Coping with Crisis in Indonesia. Institute of Southeast Asia Studies, Singapore. Amsterdam University Press. (2011)

[6] Rofi Wahanisa, Aprila Niravita, Benny Riyanto "Juridical Review of the Existence of Bengkok Land in Indonesian National Land Law" Advances in Social Science, Education and Humanities Research Volume 192. Proceedings of the 1st International Conference on Indonesian Legal Studies (ICILS 2018). Atlantis Press p 167-171 (2018)

[7] A. Muhammad, Legal Science and Legal Research. Bandung: PT. Citra Aditya Bhakti.(2004)

[8] S. Soekanto, \& S Mamudji. Normative Legal Research: A Brief Review. Jakarta: RajaGrafindo Persada. (2012)

[9] Kushartati Budiningsih, Sulistya Ekawati \& Handoyo. Analysis of the Dynamics of Forest Land Use Policy: A Content Analysis of Policy Change of Use of Forest Area. Jurnal Analisis Kebijakan Vol. 13 No. 1, April 2016: 13-28 (2016)

[10] Letter of the Governor of Central Java concerning the Agreement on the Exchange of Village Cash Land in the Tegal Regency for the construction of the Pejagan-Pemalang toll road (2017)

[11] Committing Officer of the Semarang-Solo Toll Road Development Commitment. List of Village Land Used for Semarang-Solo Toll Road Development Section IV (2015)

[12] Senthot Sudirman. "Pembangunan Jalan Tol di Indonesia: Kendala Pembebasan Tanah Untuk Pembangunan bagi Kepentingan Umum dan Gagasan Upaya Penyelesaiannya. Bhumi Jurnal Ilmiah Pertanahan PPPM-STPN Nomor 40 Tahun 13, Oktober 2014 . (Yogyakarta: STPN Press, 20 p 536 (522-544) (2014)

[13] Suhadi. The Use of Forest Areas for Infrastructure Development under Leasehold Forest Area License: A Sustainable Development Perspective. SHS Web Conference 54, 03013 (2018)

[14] Rani Dewi Kurniawati. "Akibat Hukum Terhadap Alih Fungsi Tanah Bengkok Sebagai Akibat Pembangunan Bandara Internasional Kertajati Kabupaten Majalengka". Tesis. Magister Ilmu Hukum. Universitas Pasundan. (2017) 